\title{
Wetland an Economical Solution for Wastewater Rehabilitation
}

\author{
Mamdouh F. Abdel-Sabour \\ Nuclear Research Center, Cairo, Egypt \\ Email:Wise2007egy@yahoo.com
}

Received 26 May 2014; revised 16 July 2014; accepted 26 August 2014

Copyright (C) 2014 by author and OALib.

This work is licensed under the Creative Commons Attribution International License (CC BY). http://creativecommons.org/licenses/by/4.0/

(c) (i) Open Access

\begin{abstract}
Wetland system relies on renewable energy sources such as solar and kinetic energy and wetland plants and micro-organisms, which are the active agents in the treatment process. Wetlands can remove inorganic nutrients, heavy metals, dissolved organic carb on, particulate organic matter, and suspended solids from the water column and sediments, as well as play a key role in supporting food webs and influencing global climate change through their role in methanogenesis. Using constructed wetlands, wastewater can be treated at lower costs than other treatment options, with low-technology methods where no new or complex technological tools are needed. The system relies on renewable energy sources such as solar and kinetic energy and wetland plants and micro-organ isms, which are the active agents in the treatment process. There are inherent limitations to the effectiveness of constructed wetland treatment system for wastewater treatment. Nevertheless, wetland treatment is often the best choice for treatment or pre-treatment of wastewater because of its low maintenance cost and simplicity of operation, high efficiency. Moreover, wetland techniques enhance the aesthetic value of the local and conserve the fauna and flora.
\end{abstract}

\section{Keywords}

Phytoremediation, Wastewater Treatment

Subject Areas: Edaphology, Environmental Sciences

\section{Introduction}

Increasingly stringent discharge requirements are needed to protect the environment and to prevent further degradation of water quality. Sewage/community wastewater constitutes the largest liquid waste in cities and is heterogeneous with regard to both microbial and chemical composition. Various methods were developed starting with simple holding ponds to complex mechanized treatment plants for waste water treatment. Recent attention 
has been drawn towards the use of eco-friendly system, the natural or artificial wetland to treat domestic wastewater. Under biological means, rhizosphere treatment technology is a new technology, which is a cheaper alternative for wastewater treatment using local resources. Jenssen et al. [1]; Metcalf and Eddy, Inc. [2] and Siedel [3] demonstrated that significant removal of pollutants were possible when contaminated water was passed through beds of reed plants.

Examples of simpler phytoremediation systems (Figure 1) that have been used for years are engineered constructed wetlands, often using cattails to treat acid mine drainage or municipal sewage (Kadlec [4] and Kadlec, and Knight [5].

Phytoremediation of a site contaminated with heavy metals and/or radionuclides involves "farming" the soil with selected plants to "biomine" the inorganic contaminants, which are concentrated in the plant biomass [6] [7]. For soils contaminated with to xic organics, the approach is similar, but the plant may take up or assist in the degradation of the organic contaminant [8]. Several sequential crops of hyper accumulating plants could poss ibly reduce soil concentrations of toxic inorganics or organics to the extent that residual Phytoremediation concentrations would be environmentally acceptable and no longer considered hazardous. The potential also exists for degrading the hazardous organic component of mixed contamination, thus reducing the waste (which may be sequestered in plant biomass) to a more manageable radioactive one.

For treating contaminated wastewater, the phytoremediation plants are grown in a bed of inert granular substrate, such as sand or pea gravel, using hydroponic or aeroponic techniques (Figure 2). The wastewater, supplemented with nutrients if necessary, trickles through this bed, which is ramified with plant roots that function as a biological filter and a contaminant uptake system. An added advantage of phytoremediation of wastewater is the considerable volume reduction attained through evapotranspiration [9]-[11].

In appropriate situations, phytoremediation can be an alternative to the much harsher remediation technologies of incineration, thermal vaporization, solvent washing, or other soil washing techniques, which es sentially destroy the biological component of the soil and can drastically alter its chemical and physical characteristics as well, creating a relatively nonviable solid waste. Phytoremediation actually benefits the soil, leaving an improved, functional, soil ecosystem at costs estimated at approximately one-tenth of those currently adopted technologies.

\section{How Wetlands Work?}

Wetlands are commonly known as biological filters, providing protection for water resources such as lakes, estuaries and ground water. Wetlands can be identified as areas where the water table remains close enough to or above the ground surface to maintain saturated and therefore anaerobic soil condition, supporting predominantly aquatic plants (Typha latifolia, Phragmitis australis, Saccarum spontaneum, Cyperus pangorei, Cyperus rotundus, Cyanodon dactylon and Cyperus tactus). They present a transition between aquatic and terrestrial environment and contain features of both [13].

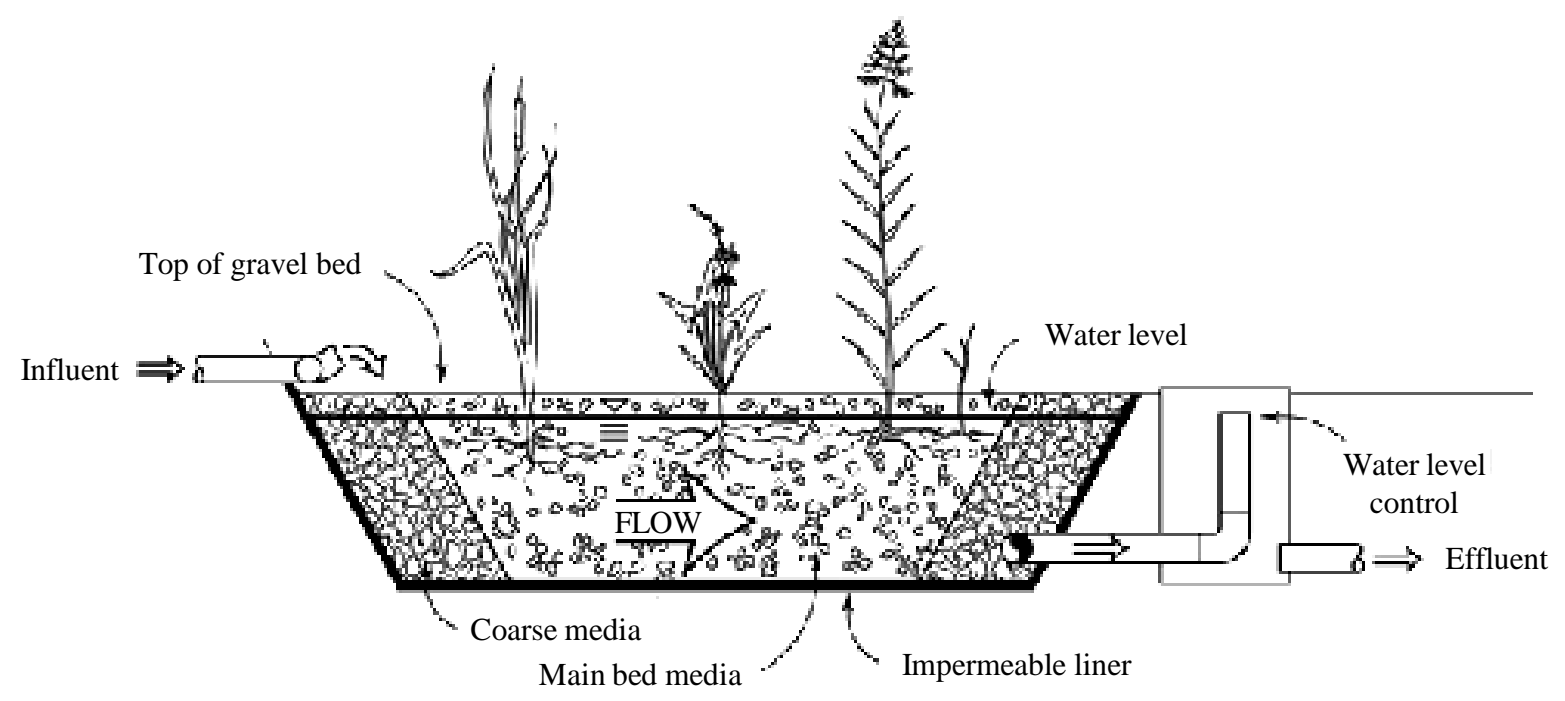


Figure 1. Engineered basin wet land (GBT).

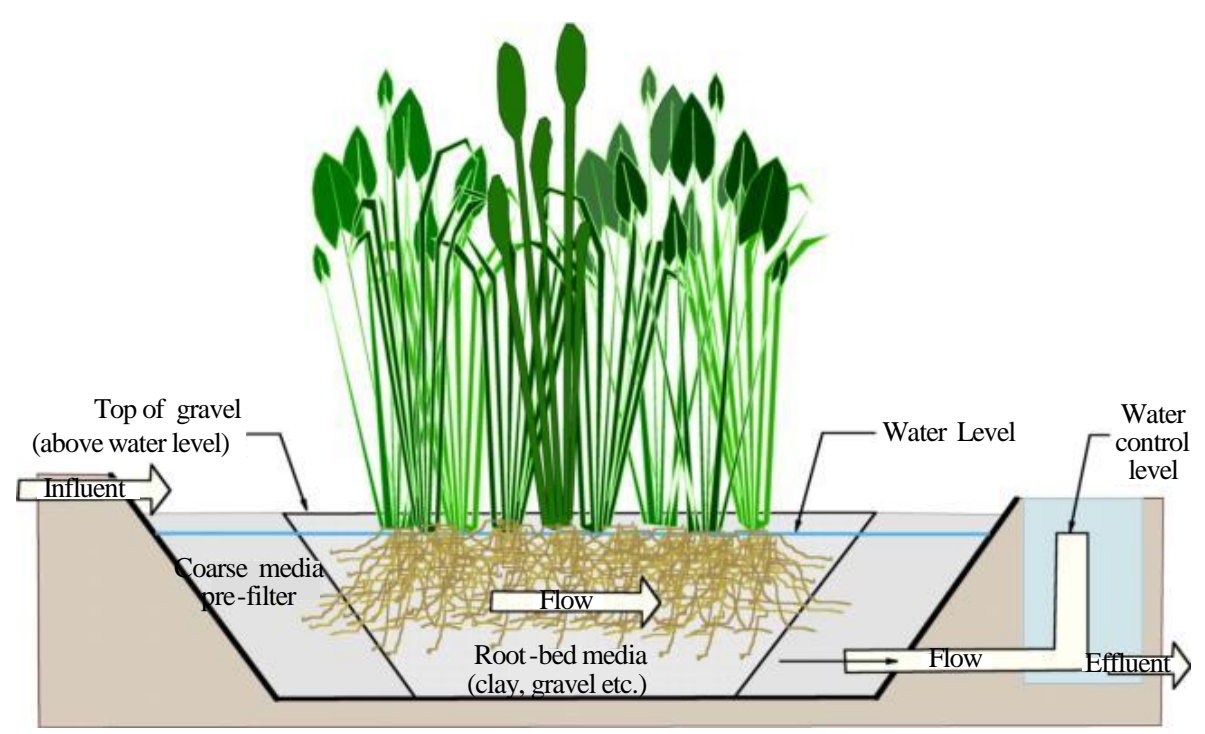

(a)

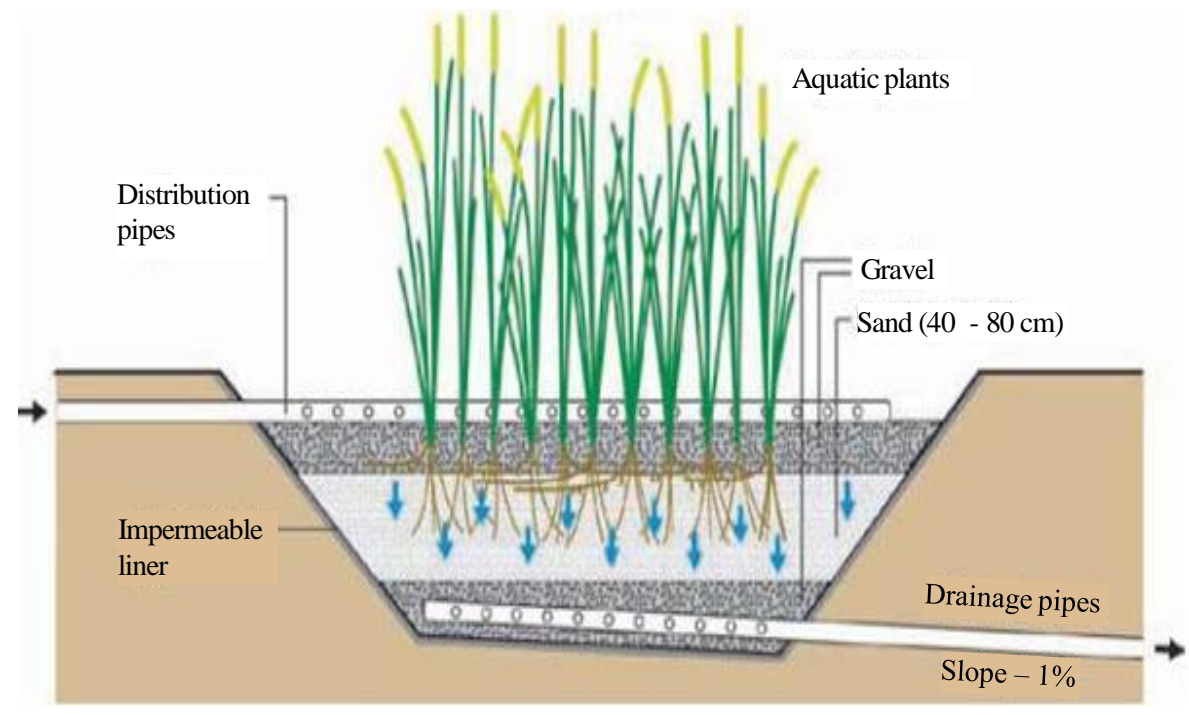

(b)

Figure 2. Subsurface (a) and Surface (b) flow of effluent [12].

Natural and constructed wetland systems have been used for treatment of domestic agricultural and industrial wastewater; even metal enriched acid load drainage [14] [15]. They do not only possess good potential for decreasing nutrient and heavy metal load in sewage effluent but also acts as an alternative low cost, low maint enance method for sewage treatment [16] [17].

In the wetland system purification of the applied wastewater takes place naturally in the living soil (or) sediment consisting of mineral and organic elements, air, water and microbial flora and fauna, as well as through the roots of plants [18]. The nutrients and metals may be removed from the polluted water and retained in the sediment and taken up by the plants and by micro-organis ms as sociated on the surface of the roots and sediments, by immobilization in sediments via, mechanis m such as adsorption on ion exchange sites bind ing to organic matter, incorporation into lattice structure and precipitates into insoluble compounds [15].

Wetland technology involves the use of plants for wastewater treatment. Indeed the removal of pollutants and the consequent wastewater purification are the results of a series of processes, which in volve reaction and inter- 
action among substratum, micro-organisms and plants, and hence the process is otherwise aptly termed as "rhizo-sphere biological treatment" as the root zone micro-flora plays a chief role in pollutant removal.

\section{Constructed Wetland Treatment and Designs}

Constructed wetlands have been developed for industrial effluent treatment and the technique exploits the natural ability of the reeds to transfer large quantities of oxygen from the atmosphere to its root zone where bacteria in the soil effect biological removal of pollutants. Both aerobic and anaerobic microorganis ms are active in the rhizosphere due to the development of aerobic and anaerobic zones in the reed bed. Constructed wetlands consist of soil filled beds with aquatic plants. Wastewater is treated when flowing through these beds [14]. In Europe common reed (Phrag mitis) is found in most systems [19], whereas in the United States bulrush (Scirpus) and Cattail (Typha) are the most common plant species. Investigation has shown that systems with plants achieved better purification performance than systems without plants [15]. Constructed wetlands or reed beds offer potentially low cost, low maintenance biological and physical methods for wastewater treatment and they are effective for decreasing BOD and ammonia concentrations (>50\% removal) in final effluents [16]. Wetlands can remove inorganic nutrients, heavy metals, dissolved organic carbon, particulate organic matter, and suspended solids from the water colu mn and sediments, as well as play a key role in supporting food webs and influencing global climate change through their role in methanogenesis [17]. Particular attention has been focused on the use of constructed wetland in the treatment of domestic sewage and many workers [18] [20]-[23] have observed significant improvements in water quality in these systems. Such systems have also been used in the treatment of a wide range of effluents including those from abattoirs [24], chemical plants and acid runoff from a mining spoil [25], dairies [26] and municipal [27].

Although broad spectrum of designs has been used for wetland treatment systems, all can be classified as either surface flow (SF) or subsurface flow (SSF) systems.

\subsection{Surface Flow Design (SF)}

The SF design typically incorporated a shallow layer of surface water, flowing over mineral (sandy) or organic (peat) soil. Free water surface wetlands are typically long and narrow to minimize short-circuiting [20]. Constructed wetland designs were based largely upon the guidelines of the Tennessee Valley Authority, which has been utilizing constructed wetland treatment systems for small communities and individual homes since 1986 [28]. The design of the hydraulic loading in the systems usually is based on measured water usage.

\subsection{Subsurface Flow Design (SSF)}

A subsurface wetland system consists of channels (or) basins that contain gravel (or) sand media (Figures 3-5) which will support the growth of emergent vegetation, the bed of impermeable material is sloped typically between 0 - 2 percent. Wastewater flows horizontally through the root zone of the wetland plants about $100-150$ $\mathrm{mm}$ below the gravel surface. Treated effluent is collected in an outlet channel or pipe as reported by [21].

A number of physical, chemical and bio logical processes operate concurrently in constructed wetlands to provide efficient contaminant removal [29]. Knowledge of the basic concepts of these processes is extremely helpful, for assessing the potential applications, benefits and limitations of wetland treatment system.

\section{Contaminant Removal}

\subsection{Suspended Solids Removal}

Wetlands are capable of achieving a high efficiency of Suspended solids removal from the water colu mn. Tu rbidity, which is primarily caused by suspended particulate matter, is sometimes used as a substitute measurement of TSS. Suspended matter in water may contain a number of types of contaminants, such as nutrients, heavy metals and organic compounds. The removal mechanis m consists of sedimentation, filtration and absorption [22]. In cases where the bulk of contaminant load is associated with particulate matter, physical settling of suspended solids can result in efficient removal of the contaminants from the water or wastewater streams [23]. The surface forces responsible for the reduction of suspended solids include Vander Waal's force of attractions and electric forces, which may be attractive or repulsive depending on the surface chargers, particles smaller than pore size may be trapped within the filter by chance contact. 


\subsection{BOD Removal}

BOD is the commonly used parameter for biological available $\mathrm{C}$, which is a measure of the rate of $\mathrm{O}_{2}$ consumpRoot Zone

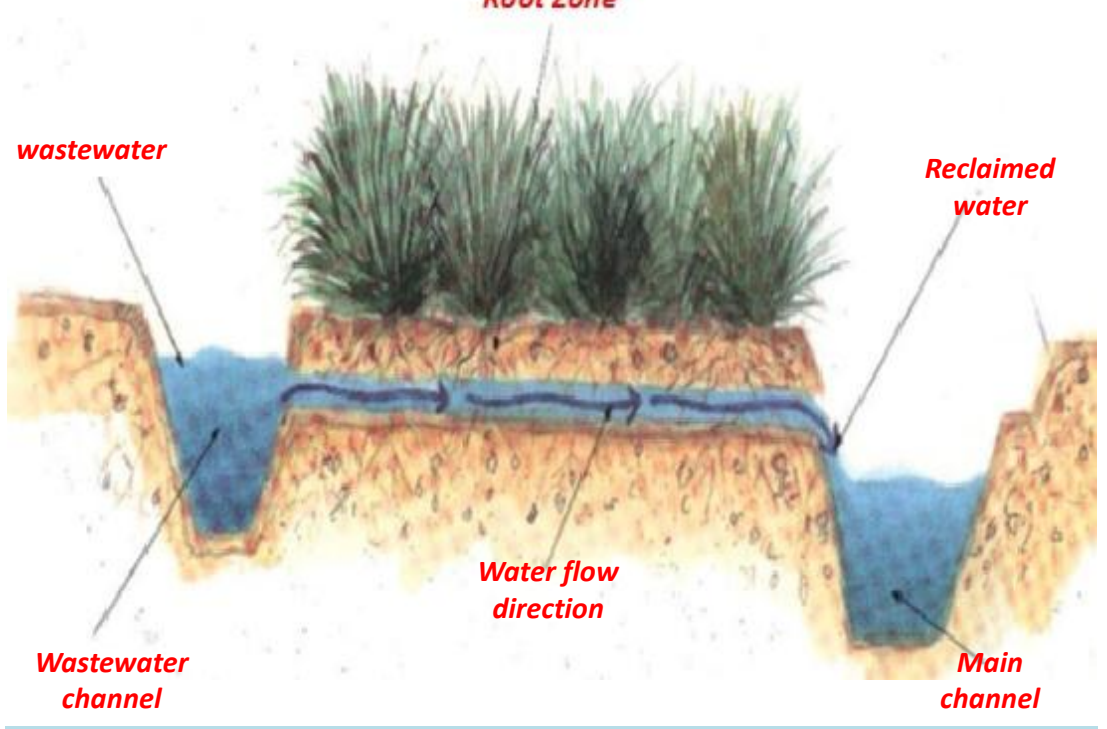

Figure 3. Simple illustrations of wetland mechanism.
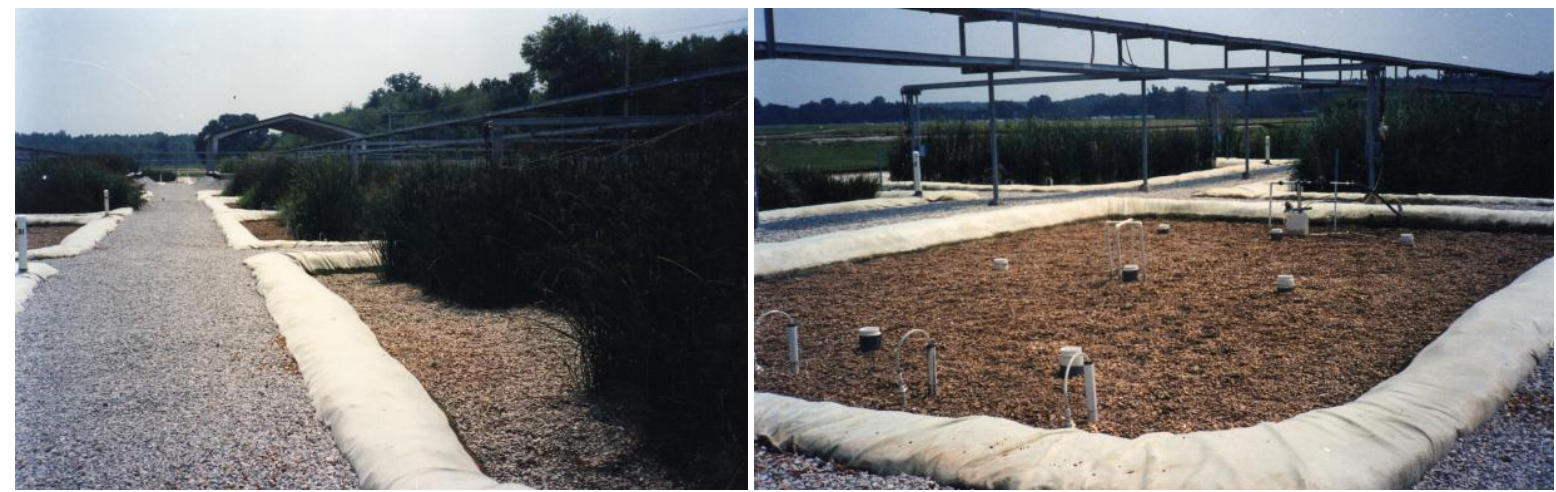

Figure 4. Engineered constructed wetland. 


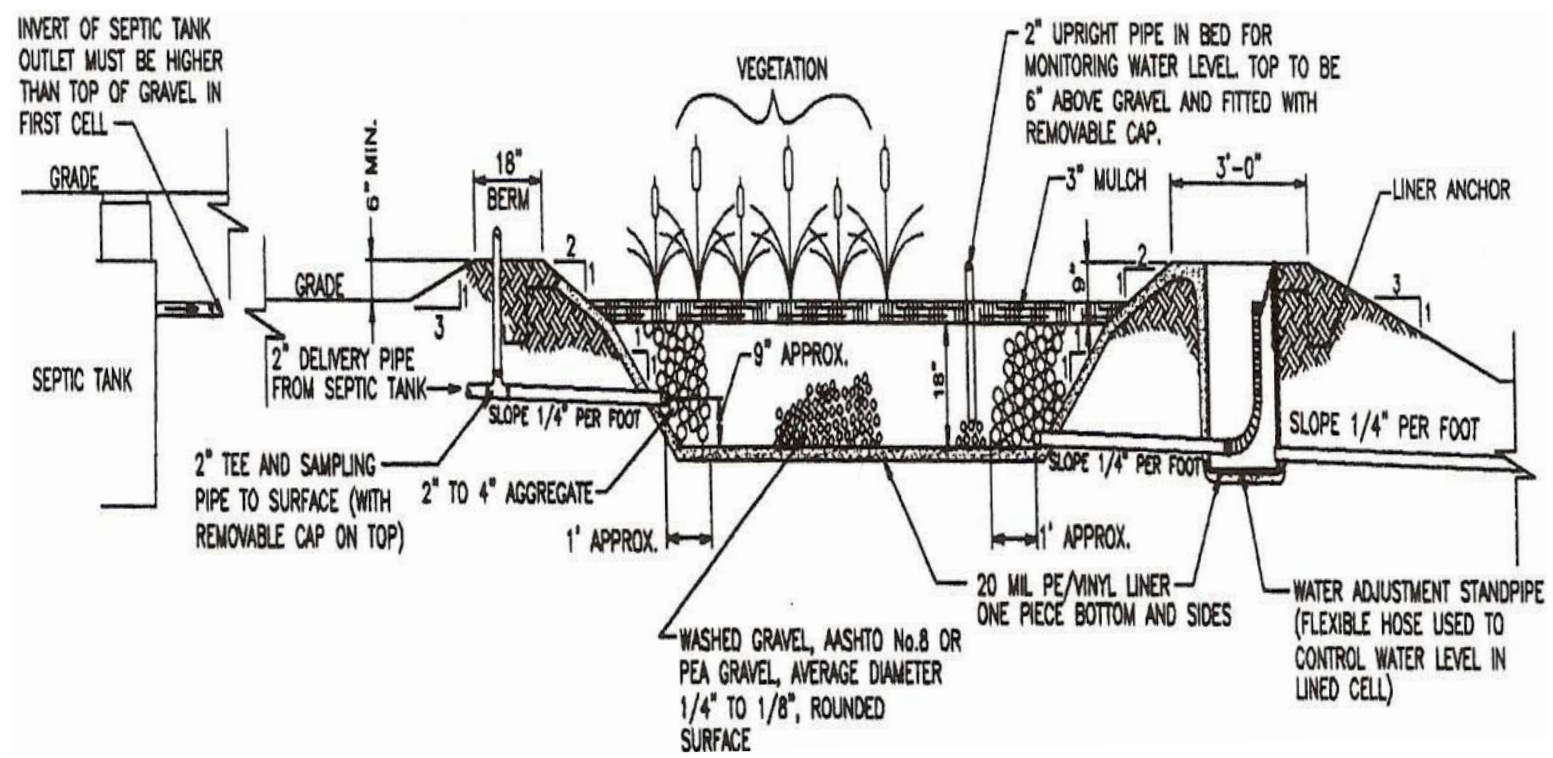

Figure 5. Schematic diagram for engineered wet land design.

tion by micro-organis ms utilizing the available organic carbon in the water or soil. The more readily degradable organic carbon compounds typically found in municipal wastewater can be rapidly removed in wetlands. Wetlands contain vast number of organic carbon utilizing mic ro-organisms adapted to the aerobic $\left(\mathrm{O}_{2}\right.$-rich $)$ surface waters and anaerobic $\left(\mathrm{O}_{2}\right.$-depleted) soils. The removal of BOD may be due to sedimentation and degradation of organic substances to $\mathrm{CO}_{2}, \mathrm{H}_{2} \mathrm{O}$ and $\mathrm{NH}_{3}$ by micro-organisms attached to plant and sedimentation surface [23].

\subsection{Nitrogen Removal}

Nitrogen is a major component of municipal wastewater and waste water from various types of industrial processes. Env iron mental and health problems as sociated with excessive a mounts of certain forms of nitrogen have been well documented. High concentrations of nitrate in d rin king water can cause methemoglobinemia, or "blue baby" syndrome, in infants. Wetlands are generally well suitable for nitrogen removal. Substantial removal of N may take place through settling of $\mathrm{N}$ containing particulate matter in the wetland inflow. The removal of nitrogen from the wastewater by rhizo-sphere treatment technology may be effected by four ways, of which nitrification and de-nitrification are noteworthy. Ammonia is oxidized to nitrate by nitrifying bacteria in aerobic zones, nitrates converted to $\mathrm{N}_{2}$ gas by denitrify ing bacteria in anoxic zones and a little removal by plant uptake as immobilization and ammonia volatilization. In addition, since nitrogen is essential plant nutrient, it can be removed through plant uptake of ammonium or nitrate, and stored in organic form in wetland vegetation [30]. Ammonium may be chemically bound in soil on a short-term basis, while organic nitrogen from dead plant material can accumulate in the soil as peat, a long term storage mechanism.

\subsection{Phosphorus Removal}

Phosphorus like nitrogen is a major plant nutrient; hence addition of $\mathrm{P}$ to the environment often contributes to eutrophication of lakes and coastal waters. In many cases, wetlands do not provide the high level of long-term P removal for $\mathrm{P}$ that they provide for $\mathrm{N}$. This is due, in part, to the lack of a metabolic pathway for $\mathrm{P}$ removal, as compared to de-nitrification for $\mathrm{N}$ re moval [23]. Net burial either in the wetland (as organic or particulate material) effectively removes the phosphorus from the water column. This phosphorus is then not immediately available for uptake by blue green algae [24] and individually suggested that physical adsorption on sorption sites rapidly removes phosphorous from the soil solution, hydroxides and oxides of Al and Fe, calcium carbonate and layer silicate minerals are important sites for sorption of phosphate anions. More than 99 percent of the wastewater phosphorous was removed after percolating through the soil solution. Usually phosphorus is available as soluble phosphorus and particulate phosphorus in the wastewater. The latter is largely attached to soil and organic particles and this is potentially removable from the water by physical process of settlement un- 
der appropriate condition [31].

\subsection{Trace Metal Removal}

A number of metals are required in s mall amounts for plant and animal growth. Some of these micronutrients, such as copper, seleniu mand zinc are to xic at higher concentrations and the bio-magnification of these can lead to health hazards to higher organis ms, including humans. A number of metals, including $\mathrm{Cd}, \mathrm{Cu}, \mathrm{Ni}, \mathrm{Pb}$ and $\mathrm{Zn}$ form nearly insoluble compounds with sulfides under anaerobic conditions in wetland soils [23]. In addition to physical and chemical adsorption of heavy metals, oxide formation is an important mechanism for metal removed from soil solution [27]. The mechanis ms involved in heavy metal sorption in soil/sediment are either adsorption on ion-exchange sites, incorporate into the lattice structure, or precipitation as insoluble oxides and sulfides. In addition, metal ions may be adsorbed within iron and manganese colloidal hydroxides or complet ed by organic compound such as humic and fulvic acid.

\subsection{Removal of Toxic Organic Compounds}

In addition to the easily degradable organic $\mathrm{C}$ compound collectively referred to as BOD, there are a multitude of degradation-resistant and toxic natural and man-made organic compounds that may be present in wastewater. Both mineral and organic soils may absorb organic compounds via chemi-sorption (strong interaction) or physical adsorption (weak interaction). Microbes are capable of degrading most classes of organic pollutants, but the rate of degradation varies considerably, depending on chemical and structural properties of the organic compound and the chemical and physical environment in the soil. Other possible mechanisms for removal of organics in wetlands are volatilization and photochemical degradation [23].

\subsection{Pathogen Removal}

A preliminary study conducted by [32] accepted that wetland systems have excellent pathogen removal capability. Sedimentation and filtration are the two physical factors, which reduce pathogen in wastewater. Competition and natural die-off are natural phenomenon for disinfection. The pathogen attenuation mechanisms unique to reed beds include attenuation by dense stand of reeds, predation by protozoa and exposure to antibiotic excretions from the roots of macro-phytes within the reed beds [33].

\section{Conclusion}

Using constructed wetlands, wastewater can be treated at lower costs than other treatment options, with lowtechnology methods where no new or complex technological tools are needed. The system relies on renewable energy sources such as solar and kinetic energy and wetland plants and micro-organis ms, which are the active agents in the treatment process. There are inherent limitations to the effectiveness of constructed wetland treatment system for wastewater treatment. Nevertheless, wetland treatment is often the best choice for treat ment or pre-treatment of wastewater because of its low maintenance cost and simplicity of operation, high efficiency. Moreover, wetland techniques enhance the aesthetic value of the local and conserve the fauna and flora.

\section{References}

[1] Jenssen, P.P., Maehlum, T. and Krogstad, T. (1993) Potential of Constructed Wetlands for Wastewater Treatment in Northern Environments. Water Science and Technology, 28, 149-157.

[2] Metcalf and Eddy, Inc. (1991) Waste Water Engineering: Treatment, Disposal and Reuse. 3rd Edition, McGraw-Hill, New York, 265.

[3] Siedel, K. (1978) Macrophyte and Water Purification Biological Control of Water Pollution. In: Toubier, J. and Pierson Jr., R.W., Eds., Biological Control of Water Pollultion, Pennsylvania Press, Philadelphia.

[4] Kadlec, R.H. (1995) Overview: Surface Flow Constructed Wetlands. Water Science and Technology, 32, 1-12. http://dx.doi.org/10.1016/0273-1223(95)00599-4

[5] Kadlec, R.H. and Knight, R.L. (1996) Treatment Wetlands. Lewis Publishers, Boca Raton, 893 p.

[6] Ross, S. (1994) Toxic Metals in Soil-Plant Systems. John Wiley and Sons Ltd., New York.

[7] Salt, D.E., Blaylock, M., Kumar, N.P.B.A., Dushenkov, V., Ensley, B.D., Chet, I. and Raskin, I. (1995) Phy toremedia- 
tion-A Novel strategy for the Removal of Toxic Metals from the Environment Using Plants. Biotechnology, 13, 468474. http://dx.doi.org/10.1038/nbt0595-468

[8] Schnoor, J.L., Licht, L.L., McCutcheon, S.C., Wolfe, N.L. and Carreira, L.H. (1995) Phytoremediation of Organic and Nutrient Contaminants. Environmental Science \& Technology, 29, 318A-323A. http://dx.doi.org/10.1021/es00007a747

[9] Hinchman, R. and Negri, C. (1994) The Grass Can Be Cleaner on the Other Side of the Fence. 1994. Logos, Argonne National Laboratory, Vol. 12, 8-11.

[10] Fritioff, Å. and Greger, M. (2003) Aquatic and Terrestrial Plant Species with Potential to Remove Heavy Metals from Stormwater. International Journal of Phytoremediation, 5, 211-224. http://dx.doi.org/10.1080/713779221

[11] Aksorn, E. and Visoottiviseth, P. (2004) Selection of Suitable Emergent Plants for Removal of Arsenic from Arsenic Contaminated Water. ScienceAsia, 30, 105-113. http://dx.doi.org/10.2306/scienceasia1513-1874.2004.30.105

[12] Okurut, T.O., Rijs, G.B.J. and Van Bruggen, J.J.A. (1999) Design and Performance of Experimental Constructed Wetlands in Unganda, Planted with Cyperus papyrus and Phragmites mauritianus. Water Science and Technology, 40, 265-271. http://dx.doi.org/10.1016/S0273-1223(99)00421-7

[13] Hammer, D.A. and Bastian, R.K. (1989) Wetland Ecosystem Natural Water Purifiers. In Constructed Wetlands for Wastewater Purifiers. In: Hammer, D.A., Ed., Constructed Wetlands for Waste Water Treatment: Municipal, Industrial and Agriculture, Proceedings, First International Conference of Constructed Wetlands for Waste Water Treatment, Chattanooga, 13-17 June 1988, 508-514.

[14] Traftner, R.B. and Woods, S.J.E. (1989) The Use of Wetlands for Waste/Wastewater Treatment. In: Encyclopedia of Environmental Control Technology, Gulf Publishing Company, Tokyo, 519-622.

[15] Weider, R.K. (1990) Metal Cation Binding to Sphagnum Peat and Sawdust Relation to Wetland Treatment of Metal Polluted Waters. Water, Air \& Soil Pollution, 53, 391-400.

[16] Harbison, P. (1986) Mangrove Muds-A Sink and a Source for Trace Metals. Marine Pollution Bulletin, 17, $246-250$. http://dx.doi.org/10.1016/0025-326X(86)90057-3

[17] Conley, L.M., Dick, R.I. and Lion, L.W. (1991) An Assessment of the Root Zone Method of Wastewater Treatment. Research Journal of the Water Pollution Control Federation, 63, 239-247.

[18] De Bustamante, I. (1990) Land Application: Its Effectiveness in Purification of Urban and Industrial Waste Waters in La Mancha, Spain. Environmental Geology and Water Sciences, 16, 179-185.

[19] Findlater, B.C., Hobson, J.A. and Cooper, P.F. (1990) Reed Bed Treatment System: Performance Evaluation. In: Cooper, P.F. and Findlater, B.C., Eds., Constructed Wetlands in Water Pollution Control, Pergamon Press, Oxford, 193- 204. http://dx.doi.org/10.1016/B978-0-08-040784-5.50023-1

[20] USEPA (1988) Design Manual on Constructed Wetlands and Aquatic Plant Systems for Municipal Waste Water Treatment. Washington, DC, EPA/625/1-88/022.

[21] Crites, R.W. (1994) Design Criteria and Practice for Constructed Wetlands. Water Science and Technology, 29, 1-6.

[22] Tchobanoglous, G. and Eliassen, R. (1970) Filtration of Treated Effluent. Journal of the Sanitary Engineering Division, ASCE, 96, 243-265.

[23] De Busk, W.F. (1999) Waste Water Treatment Wetlands: Application and Treatment Efficiency. FAS Extension, University of Florida, Gainesville.

[24] White, G.L., Smalls, I.C. and Bek, P.A. (1994) Carcoar Wetland-A Wetland System for River Nutrient Removal. Water Science and Technology, 29, 169-176.

[25] Manselli, R.S., Mckenna, P.J., Flaig, E. and Hall, M. (1985) Phosphate Movement in Column of Sandy Soil from a Wastewater Treated Site. Soil Science, 140, 59-68. http://dx.doi.org/10.1097/00010694-198507000-00008

[26] Cross, H.C. and White, G.C. (1990) Concoar Dan, Constructed Wetland: An Initial Assessment of Feasibility. Internal Report NSW Department of Water Resources, Sydney, 213-219.

[27] Weider, R.K. and Lang, G.E. (1986) Fe, Al, Mn and S Chemistry of Sphagnum Peat in Four Peat Lands with Different Metal and Sulphur Input. Water, Air, and Soil Pollution, 29, 309-320. http://dx.doi.org/10.1007/BF00158762

[28] Watson, J.T., Reed, S.C., Kadlec, R.H., Knight, R.L. and Whitehouse, A.E. (1989) Performance Expectations and Loading Rates of Constructed Wetlands. In: Hammer, D.A., Ed., Constructed Wetlands for WastewaterTreatment, Lewis, Chelsac, 319-351.

[29] May, E., Butler, J.E., Ford, M.G., Ashworth, R., Williams, J. and Bah gat, M.M. (1990) Chemical and Microbiological Processes in Gravel Bed Hydroponic System for Sewage Treatment. Proceedings of the International Conference on the Use of Constructed Wetlands in Water Pollution Control, Cambridge, 24-28 September 1990, 33-40. http://dx.doi.org/10.1016/B978-0-08-040784-5.50008-5 
[30] Abdel-Sabour, M.F. (2008) Environmental Solution: Part 1, Industrial and Sewage Effluents Treatments. (In Arabic) https://www.researchgate.net/profile/Mamdouh Abdel-Sabour

[31] Holford, I.C.R. and Patrick Jr., W.H. (1979) Effect of Redox Potential and pH on Phosphate Removal from Waste Water during Land Application. Progress in Water Technology, 11, 215-225.

[32] Bavor, H.J. and Andel, E.F. (1994) Nutrient Removal and Disinfection Performance in the Byron Bay Constructed Wetlands System. Water Science \& Technology, 29, 201-208.

[33] Healy, M. and Cawley, A.M. (2002) Nutrient Processing Capacity of a Constructed Wetland in Western Ireland. Journal of Environmental Quality, 31, 1739-1747. http://dx.doi.org/10.2134/jeq2002.1739 